\title{
Merancang dan Mengimplementasi Modul Praktikum Pembangkit Listrik Tenaga Mikro Hidro di Jurusan Teknik Elektro dan Komputer Universitas Udayana
}

\author{
Achmad Bahri $^{1}$, Lie Jasa ${ }^{2}$, Yanu Prapto Sudarmojo ${ }^{3}$
}

\begin{abstract}
This research aims to design an experimental module of micro-hydro power plant then implement those modules by arranging practical instructions and perform the measurement. Measurement data in the discussion of this final project was obtained from lab prototype Micro Hydro Power (MHP) is in the design. Measurements were made using three different types of turbines, turbine blade is a semi-circular, triangular blade turbine, and the turbine blade fins. The measurement results are discussed and analyzed by using formulas and computer programs Ms. Excel. Measurement procedures in lab MHP is designed to determine principle of working prototypes of MHP by measuring Currents (I), Voltage $($ V), Power (P), Water Discharge (Q), Round Turbine (nt), and Round Generator (ng) with angle nozzle $10^{\circ}, 1^{\circ}, 20^{\circ}, 25^{\circ}, 30^{\circ}$, $35^{\circ}$, and $40^{\circ}$ for each experiment, with three kinds type of turbine blades, and can determine the efficiency and regulation. Based on measurement results of the MHP prototype has been designed, the efficiency of turbine on each blade reaches its highest point at an angle of $30^{\circ}$. On the corner, the efficiency of the turbine blade semicircle at 0.26 , triangular blade turbine 0.46 and fin blade turbine efficiency at 0.38 . So from these three types of turbine blades, turbine efficiency level of the most well based on measurements of the prototype has been designed is a triangular blade turbine efficiency value 0.46 or $46 \%$.
\end{abstract}

Intisari- Penelitian ini bertujuan untuk merancang suatu modul praktikum PLTMH kemudian mengimplementasi modul tersebut dengan menyusun petunjuk-petunjuk praktikum serta melakukan pengukuran. Data hasil pengukuran dalam pembahasan didapatkan dari prototipe praktikum Pembangkit Listrik Tenaga Mikro Hidro (PLTMH) yang di desain. Pengukuran dilakukan dengan menggunakan tiga jenis turbin, yaitu turbin sudu setengah lingkaran, turbin sudu segitiga, dan turbin sudu sirip. Hasil pengukuran tersebut dibahas dan dianalisis dengan menggunakan rumus dan program komputer Ms. Excel. Prosedur pengukuran dalam praktikum PLTMH dirancang untuk mengetahui prinsip kerja prototype PLTMH dengan mengukur Arus (I), Tegangan (V), Daya (P), Debit Air (Q), Putaran Turbin (nt), dan Putaran Generator (ng) dengan sudut nozzle $10^{0}, 15^{0}, 20^{0}, 25^{0}, 30^{\circ}, 35^{\circ}$, dan $40^{\circ}$ untuk setiap percobaan, dengan tiga macam jenis sudu turbin, serta dapat menentukan efisiensi dan regulasinya.

${ }^{1}$ Mahasiswa, Jurusan Teknik Elektro dan Komputer Fakultas Teknik Universitas Udayana, Perum Puri Jimbaran Bali(Hp: 085718826816; telp: -; e-mail:achmadbahrav@gmail.com)

2, 3 Staf Pengajar Jurusan Teknik Elektro dan Komputer Fakultas Teknik Universitas Udayana, Jalan Kampus Bukit Jimbaran 80361 INDONESIA (telp: 0361-703315; fax: 03614321)

Achmad Bahri: Merancang Dan Mengimplementasi Modul ...
Berdasarkan hasil pengukuran dari prototype PLTMH yang telah dirancang, efisiensi turbin pada masing-masing sudu mencapai titik tertinggi pada sudut $30^{\circ}$. Pada sudut tersebut, efisiensi turbin sudu setengah lingkaran sebesar 0.26 , turbin sudu segitiga sebesar 0.46 dan efisiensi turbin sudu sirip sebesar 0.38. Sehingga dari ketiga jenis sudu turbin tersebut, tingkat efisiensi turbin yang paling baik berdasarkan hasil pengukuran dari prototype yang telah dirancang adalah turbin sudu segitiga yang nilai efisiensinya sebesar 0.46 atau $46 \%$.

Kata Kunci- PLTMH, Prosedur Praktikum, Sudu Turbin, Efisiensi.

\section{Pendahuluan}

Teknik Elektro dan Komputer Universitas Udayana mempunyai 114 mata kuliah dan 10 mata kuliah praktikum. Dengan mempelajari ilmu dari teori, mahasiswa juga diajarkan dalam hal praktikum. Hal tersebut dilakukan agar mahasiswa tidak hanya mempelajari ilmu di kelas saja, akan tetapi di terapkan di Laboratorium dengan sistem praktikum agar ilmu yang diajarkan dapat langsung diterapkan.

Terdapat tujuh laboratorium di Jurusan Teknik Elektro dan Komputer Universitas Udayana, yaitu Lab. Workshop dan Instalasi Listrik, Lab. Teknik Digital dan Mikroprosesor, Lab. Dasar Teknik Elektro, Lab. Sistem Telekomunikasi, Lab. Konversi Energi, Lab. Teknik Kendali, Lab. Riset Manajemen Energi Listrik, dan Lab. Komputer. Namun sejauh ini belum terdapat kurikulum yang mengajarkan tentang energi terbarukan atau energi alternatif, dengan kata lain jurusan Teknik Elektro dan Komputer perlu disusun suatu kurikulum terkait dengan hal tersebut.

Dalam penelitian ini, penulis membuat suatu modul praktikum Pembangkit Listrik Tenaga Mikro Hidro (PLTMH) sebagai bahan ajar untuk mahasiswa di Jurusan Teknik Elektro dan Komputer Universitas Udayana. Dalam modul ini, penulis ingin membuat suatu pemahaman mendalam tentang PLTMH yang di tunjang dengan suatu praktikum, praktikum tersebut berisi tentang pemahaman prinsip kerja, sistem pengukuran serta regulasi lainnya.

\section{Modul Praktikum Mikro Hidro}

\section{A. Teori Dasar Aliran}

Air yang mengalir mempunyai energi yang dapat digunakan untuk memutar roda turbin, karena itu pusat-pusat tenaga air dibangun di sungai dan didaerah pengunungan. Pusat tenaga air tersebut dapat dibedakan dalam 2 golongan, yaitu pusat tenaga air tekanan tinggi dan pusat tenaga air

p-ISSN:1693 - 2951; e-ISSN: 2503-2372 
tekanan rendah. Dengan menggunakan pipa, air tersebut dialirkan ke rumah pusat tenaga, yang dibangun dibagian bawah bendungan, dan didalam rumah tersebut telah dipasang sebuah nozzle, lewat nozzle itulah air akan menyemprot ke luar dan memutar roda turbin, kemudian air tersebut dibuang ke sungai. Diperlukan jumlah air yang konstan untuk memutar turbin air, sehingga putaran generator juga konstan [1]. Dari selisih tinggi permukaan air atas dan permukaan air bawah terdapat tinggi air jatuh (h). Dengan menggunakan rumusrumus mekanika fluida, daya turbin, luas penampang lintang saluran dan dimensi bagian-bagian turbin lainnya serta bentuk energi dari aliran air dapat ditentukan. [2]

1) Perhitungan Debit Air: Debit merupakan salah satu parameter penting dalam perencanaan PLTMH. Ukuran debit air akan menentukan besarnya energi yang mampu dihasilkan. Untuk menghitung debit air yang mengalir, digunakan rumus :

$$
\text { Debit }=\frac{\text { Volume Bejana }}{\text { Waktu untuk memenuhi bejana }}
$$

2) Tinggi Jatuh Air (Head): Untuk mendapatkan tinggi jatuh air $(h)$ dilakukan pengukuran dengan menggunakan metode water-filled tube dimana diukur dari permukaan air atas pada nozzel hingga air menyentuh sudu pada runner turbin. Sehingga tinggi jatuh air pada prototype PLTMH didapatkan sebesar 0,6 meter.

3) Perhitungan Daya Input (Pin): Setelah diperoleh besarnya debit dan head, maka dapat ditentukan besarnya daya input (Pin) yang dihasilkan dengan rumus [3]:

$$
\begin{aligned}
& \text { Pin }=\rho \cdot Q \cdot g \cdot h \\
& \text { Dimana: } \\
& \begin{aligned}
\text { Pin }=\text { Daya input }(\text { Watt }) \\
\rho=\text { Massa jenis air }\left(1000 \mathrm{~kg} / \mathrm{m}^{3}\right) \\
\mathrm{Q}=\text { Debit air }\left(\mathrm{m}^{3} / \mathrm{s}\right) \\
\mathrm{g}=\text { Gravitasi }\left(9,81 \mathrm{~m} / \mathrm{s}^{2}\right) \\
\mathrm{h}=\text { Tinggi jatuh air }(\mathrm{m})
\end{aligned}
\end{aligned}
$$

4) Daya Output Generator (Pout): Daya output generator dihitung berdasarkan perkalian antara tegangan dan arus yang diukur menggunakan alat yaitu multimeter. Secara matematis, daya output dirumuskan sebagai berikut [4]:

$$
\text { Pout }=\text { V.I }
$$

Dimana:

$$
\begin{aligned}
& \text { Pout }=\text { Daya keluar (Watt) } \\
& \mathrm{V} \quad=\text { Tegangan (Volt) } \\
& \mathrm{I} \quad=\text { Arus (A) }
\end{aligned}
$$

5) Perhitungan Efisiensi Masing - Masing Turbin: Efisiensi dihitung dengan membagi daya yang keluar dari generator dengan daya masuk, atau secara matematis dapat dirumuskan sebagai berikut [5]:

$$
\eta=\frac{\text { Pout }}{\text { Pin }}
$$

\section{B. Mikro Hidro}

Pembangkit Listrik Tenaga Mikro Hidro (PLTMH) adalah pembangkit listrik yang memanfaatkan air sebagai sumber penggerak utamanya serta kapasitas dari PLTMH tidak melebihi $100 \mathrm{~kW}$ [6]. Dari segi teknologi, PLTMH dipilih karena konstruksinya sederhana, mudah dioperasikan, serta mudah dalam perawatan dan penyediaan suku cadang. Secara ekonomis, biaya operasi investasinya cukup bersaing dengan pembangkit listrik lainnya. Secara sosial, PLTMH mudah diterima oleh masyarakat luas. PLTMH biasanya dibuat dalam skala desa di daerah-daerah terpencil yang belum mendapatkan listrik dari PLN. Tenaga air yang digunakan dapat berupa aliran air pada sistem irigasi, sungai yang di bendung atau air terjun. [7]

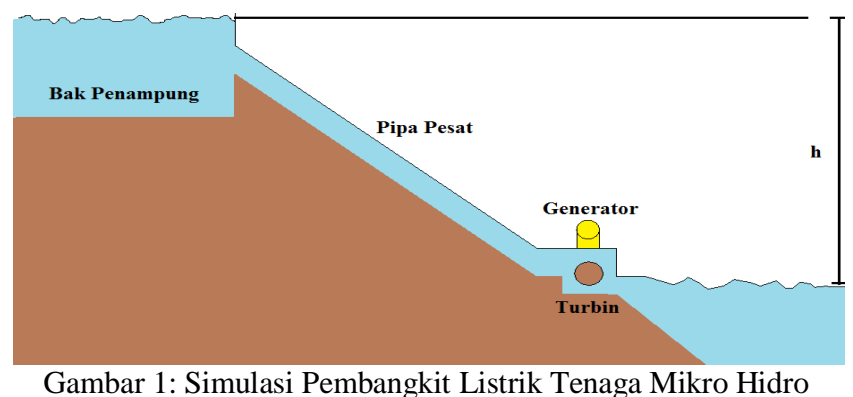

\section{Metode PERANCANGAN}

Secara sistematik alur penelitian dapat dilihat seperti pada Gambar 2.

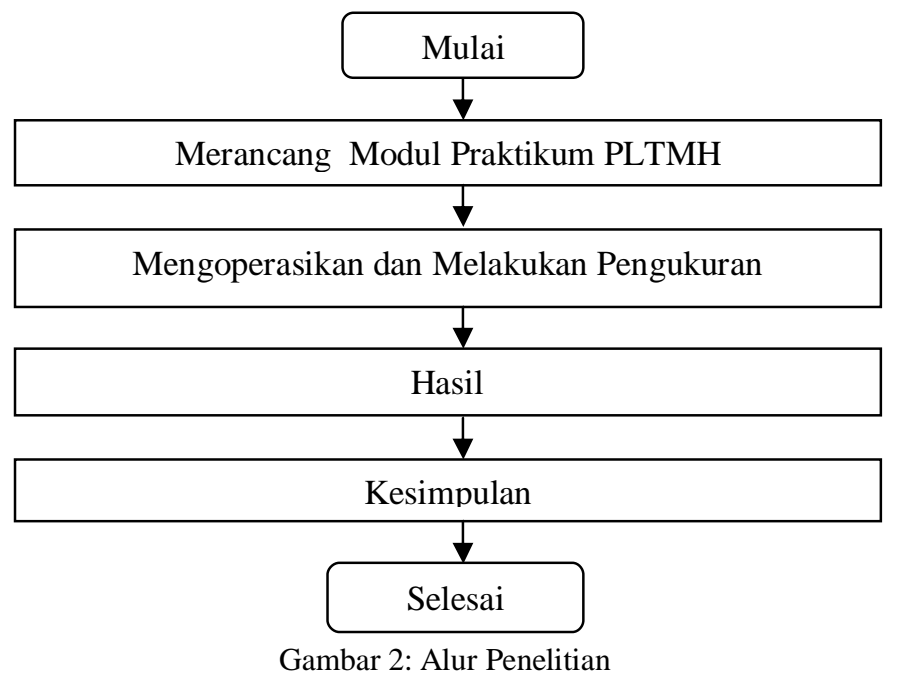

\section{A. Merancang Modul Praktikum PLTMH}

Modul praktikum dirancang berdasarkan acuan dari hasil prototype PLTMH yang telah dibuat, terkait dengan tujuan praktikum, sistem pengukuran serta sistem parameter yang dapat diukur.

1) Tujuan Praktikum

a) Mengetahui prinsip kerja dari prototipe PLTMH.

b) Mengukur I, V, P, Q, nt, ng dengan sudut nozzle $10^{\circ}$, $15^{0}, 20^{\circ}, 25^{\circ}, 30^{\circ}, 35^{\circ}$, dan $40^{\circ}$ untuk setiap percobaan, dengan tiga macam jenis sudu turbin.

c) Menentukan efisiensi dan regulasi dari modul PLTMH

2) Alat-Alat

a) Multimeter
b) Manometer 

c) Tachometer
d) Stopwatch
e) Bejana

\section{B. Mengoperasikan dan Melakukan Pengukuran}

Sebelum percobaan dengan tiga jenis sudu turbin, hal yang terlebih dahulu dihitung adalah debit air. Debit air dihitung dengan mengisi bejana dengan air yang mengalir dari nozzle dan hitung waktu yang diperlukan untuk memenuhi bejana dengan stopwatch dan catat hasil pengukuran.

Setelah menghitung debit air, selanjutnya percobaan dilakukan dengan tiga jenis sudu turbin, yaitu sudu setengah lingkaran, sudu segitiga, dan sudu sirip. Percobaan pada masing-masing jenis sudu, dilakukan dengan mengatur sudut nozzlenya sebesar $10^{\circ}, 15^{\circ}, 20^{\circ}, 25^{\circ}, 30^{\circ}, 35^{\circ}$, dan $40^{\circ}$. Pengukuran dilakukan untuk masing-masing jenis sudu dengan posisi nozzle yang sama serta pengambilan data dilakukan sebanyak 5 kali.

1) Mengatur sudut nozzle sebesar $10^{\circ}$ dengan menggunakan sudu turbin setengah lingkaran

2) Mengukur putaran turbin dan generator
a) Jalankan alat
b) Siapkan tachometer
c) Pasang tachometer pada poros pully turbin dan poros pully generator
d) Baca dan catat hasil pengukuran pada tabel 1

3) Mengukur tekanan air
a) Baca hasil pada manometer yang terpasang
b) Catat hasil pengukuran pada tabel 1

4) Mengukur tegangan
a) Siapkan multimeter
b) Pasang multimeter pada output tegangan generator c) Baca dan catat hasil pengukuran pada tabel 1

5) Mengukur arus
a) Siapkan multimeter
b) Pasang beban pada output tegangan generator
c) Ukur arus dengan multimeter
d) Baca dan catat hasil pengukuran pada tabel 1

6) Lakukan langkah yang sama seperti di atas dengan mengatur sudut nozzle sebesar $15^{\circ}, 20^{\circ}, 25^{\circ}, 30^{\circ}, 35^{\circ}$, dan $40^{\circ}$.

Lakukan keseluruhan langkah di atas pada jenis sudu turbin berbeda yaitu turbin sudu segitiga dan turbin sudu sirip.

TABEL 1

Hasil Pengukuran PrakTikUM

\begin{tabular}{|c|c|c|c|c|c|c|c|c|c|}
\hline \multirow{3}{*}{ No. } & \multirow{3}{*}{$\begin{array}{c}\text { Sudut } \\
\text { Nozzle }\end{array}$} & \multirow{3}{*}{$\begin{array}{c}\text { Tekanan } \\
\text { Air } \\
\left(\mathbf{k g} / \mathbf{c m}^{2}\right)\end{array}$} & $\begin{array}{l}\text { Tanpa } \\
\text { Beban }\end{array}$ & \multicolumn{6}{|c|}{ Berbeban (Lampu 3 Watt) } \\
\hline & & & \multirow{2}{*}{$\begin{array}{c}\mathbf{V} \\
(\mathbf{V})\end{array}$} & \multirow{2}{*}{$\begin{array}{c}\mathrm{V} \\
\text { (V) }\end{array}$} & \multirow{2}{*}{$\begin{array}{c}\text { I } \\
\text { (A) }\end{array}$} & \multirow{2}{*}{$\begin{array}{c}\mathbf{P} \\
(\mathbf{W})\end{array}$} & \multirow{2}{*}{$\mathbf{Q}$} & \multicolumn{2}{|c|}{$\begin{array}{l}\text { RPM } \\
\text { Max }\end{array}$} \\
\hline & & & & & & & & ng & nt \\
\hline
\end{tabular}

\section{HASIL DAN PEMBAHASAN}

\section{A. Hasil Prototipe PLTMH}

Berdasarkan hasil prototipe yang telah dirancang untuk melakukan praktikum PLTMH, maka pengukuran yang dapat dilakukan menggunakan alat ukur yaitu mengukur tekanan air

Achmad Bahri: Merancang Dan Mengimplementasi Modul ...

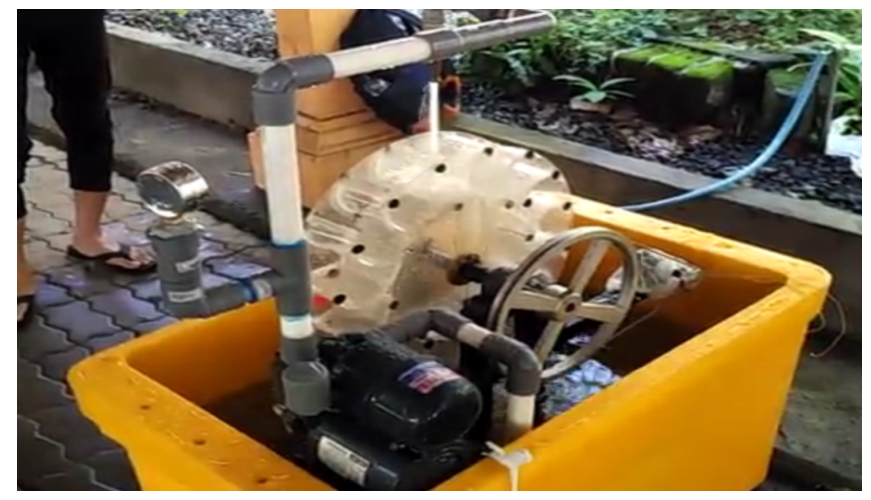

Gambar 3: Hasil Prototipe PLTMH

(Manometer), putaran turbin (Tachometer), putaran generator (Tachometer), tegangan (Multimeter), dan arus (Multimeter).

\section{B. Hasil Pengukuran}

1) Perhitungan Debit Air: Dalam pengukuran, volume bejana yang digunakan sebesar 3,8 Liter atau $0,0038 \mathrm{~m}^{3}$, dengan waktu yang diperlukan untuk memenuhi bejana yaitu 37,44 Detik. Sehinggal debit air yang mengalir dapat dihitung sebagai berikut :

$$
\begin{aligned}
\text { Debit } & =\frac{0,0038}{37,44} \\
\text { Debit } & =0,0001 \mathrm{~m}^{3} / \mathrm{s}
\end{aligned}
$$

Jadi, debit air yang dihasilkan sebesar $0,0001 \mathrm{~m}^{3} / \mathrm{s}$

2) Tinggi Jatuh Air (Head): Untuk mendapatkan tinggi jatuh air $(h)$ dilakukan pengukuran dengan menggunakan metode water-filled tube dimana diukur dari permukaan air atas pada nozzel hingga air menyentuh sudu pada runner turbin. Sehingga tinggi jatuh air pada prototype PLTMH didapatkan sebesar 0,6 meter.

3) Perhitungan Daya Input (Pin): Berdasarkan rumus, maka besarnya daya input yang dihasilkan dapat di hitung sebagai berikut :

$$
\begin{aligned}
\text { Pin } & =1000 \cdot 0,0001 \cdot 9,81 \cdot 0,6 \\
& =0,588 \text { Watt }
\end{aligned}
$$

4) Daya Output Generator (Pout): Daya output generator dihitung berdasarkan perkalian antara tegangan dan arus yang diukur menggunakan alat yaitu multimeter.

Besarnya daya keluaran dari generator pada masingmasing jenis turbin dapat dilihat pada tabel 2 .

TABEL 2

HASIL PENGUKURAN DAYA OUTPUT

\begin{tabular}{|c|c|c|c|c|c|c|c|c|c|c|}
\hline \multirow{2}{*}{ No } & \multirow{2}{*}{$\begin{array}{c}\text { Sudut } \\
\text { Nozze } \\
\end{array}$} & \multicolumn{3}{|c|}{$\begin{array}{c}\text { Sudu Setengah } \\
\text { Lingkaran }\end{array}$} & \multicolumn{3}{|c|}{ Sudu Segitiga } & \multicolumn{3}{|c|}{ Sudu Sirip } \\
\cline { 3 - 11 } & $\mathbf{V}$ & $\mathbf{I}$ & Pout & $\mathbf{V}$ & I & Pout & V & I & Pout \\
\hline $\mathbf{1}$ & $\mathbf{1 0}^{\mathbf{0}}$ & $\begin{array}{c}0.2 \\
1\end{array}$ & 0.06 & $\mathbf{0 . 0 1}$ & 0.20 & 0.06 & $\mathbf{0 . 0 1}$ & 0.20 & 0.06 & $\mathbf{0 . 0 1}$ \\
\hline $\mathbf{2}$ & $\mathbf{1 5}^{\mathbf{0}}$ & $\begin{array}{c}0.3 \\
2\end{array}$ & 0.08 & $\mathbf{0 . 0 3}$ & 0.31 & 0.07 & $\mathbf{0 . 0 2}$ & 0.24 & 0.07 & $\mathbf{0 . 0 2}$ \\
\hline $\mathbf{3}$ & $\mathbf{2 0}$ & $\begin{array}{c}0.6 \\
8\end{array}$ & 0.10 & $\mathbf{0 . 0 7}$ & 0.66 & 0.10 & $\mathbf{0 . 0 7}$ & 0.73 & 0.08 & $\mathbf{0 . 0 6}$ \\
\hline $\mathbf{4}$ & $\mathbf{2 5}^{\mathbf{0}}$ & $\begin{array}{c}1.0 \\
4\end{array}$ & 0.12 & $\mathbf{0 . 1 3}$ & 1.30 & 0.14 & $\mathbf{0 . 1 8}$ & 1.30 & 0.09 & $\mathbf{0 . 1 2}$ \\
\hline $\mathbf{5}$ & $\mathbf{3 0}^{\mathbf{0}}$ & 1.1 & 0.13 & $\mathbf{0 . 1 5}$ & 1.70 & 0.16 & $\mathbf{0 . 2 7}$ & 1.60 & 0.14 & $\mathbf{0 . 2 2}$ \\
\hline
\end{tabular}

p-ISSN:1693 - 2951; e-ISSN: 2503-2372 


\begin{tabular}{|c|c|c|c|c|c|c|c|c|c|c|}
\hline & & 5 & & & & & & & & \\
\hline $\mathbf{6}$ & $\mathbf{3 5}^{\mathbf{0}}$ & $\begin{array}{c}1.1 \\
0\end{array}$ & 0.11 & $\mathbf{0 . 1 2}$ & 1.60 & 0.13 & $\mathbf{0 . 2 1}$ & 1.50 & 0.11 & $\mathbf{0 . 1 7}$ \\
\hline $\mathbf{7}$ & $\mathbf{4 0}^{\mathbf{0}}$ & $\begin{array}{c}0.0 \\
0\end{array}$ & 0.00 & $\mathbf{0 . 0 0}$ & 0.00 & 0.00 & $\mathbf{0 . 0 0}$ & 0.00 & 0.00 & $\mathbf{0 . 0 0}$ \\
\hline
\end{tabular}

5) Perhitungan Efisiensi Masing - Masing Turbin: Perhitungan efisiensi pada masing-masing sudu turbin di tampilkan pada tabel 3 .

TABEL 3

EfISIENSI MASING-MASING Sudu TuRbin

\begin{tabular}{|c|c|c|c|c|}
\hline \multirow{2}{*}{ No. } & \multirow{2}{*}{$\begin{array}{c}\text { Sudut } \\
\text { Nozzel }\end{array}$} & $\begin{array}{c}\text { Sudu Setengah } \\
\text { Lingkaran }\end{array}$ & Sudu Segitiga & Sudu Sirip \\
\hline $\mathbf{1}$ & $\mathbf{1 0}^{\mathbf{0}}$ & 0.02 & 0.02 & 0.02 \\
\hline $\mathbf{2}$ & $\mathbf{1 5}^{\mathbf{0}}$ & 0.04 & 0.04 & 0.03 \\
\hline $\mathbf{3}$ & $\mathbf{2 0}^{\mathbf{0}}$ & 0.12 & 0.11 & 0.09 \\
\hline $\mathbf{4}$ & $\mathbf{2 5}^{\mathbf{0}}$ & 0.22 & 0.30 & 0.20 \\
\hline $\mathbf{5}$ & $\mathbf{3 0}^{\mathbf{0}}$ & 0.26 & 0.46 & 0.38 \\
\hline $\mathbf{6}$ & $\mathbf{3 5}^{\mathbf{0}}$ & 0.20 & 0.35 & 0.29 \\
\hline $\mathbf{7}$ & $\mathbf{4 0}^{\mathbf{0}}$ & 0.00 & 0.00 & 0.00 \\
\hline
\end{tabular}

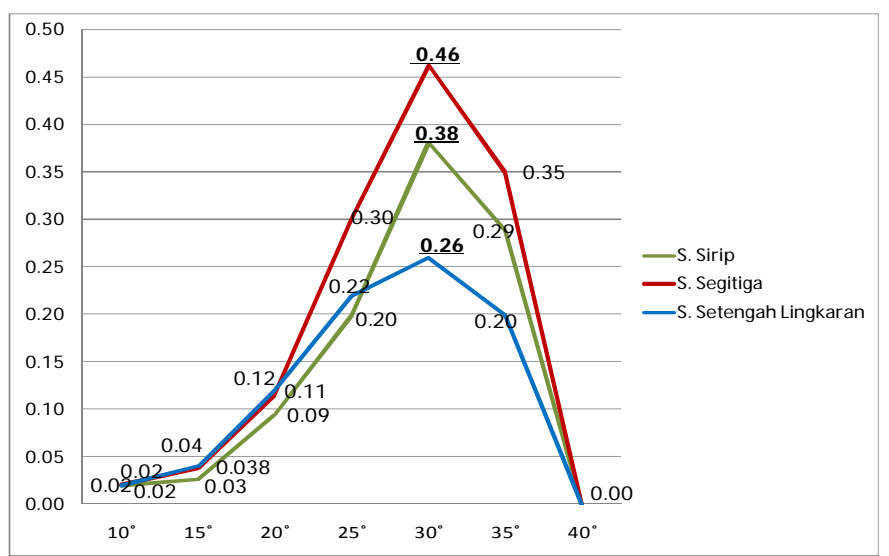

Gambar 4: Perbandingan Efisiensi Tiga Sudu Turbin

Batas maksimal efisiensi pada turbin sebesar $100 \%$ atau 1. Berdasarkan hasil pengukuran dari prototype PLTMH yang telah ada, efisiensi turbin pada masing-masing sudu mencapai titik tertinggi pada sudut $30^{\circ}$. Pada sudut tersebut, efisiensi turbin sudu setengah lingkaran sebesar 0.26, turbin sudu segitiga sebesar 0.46 dan efisiensi turbin sudu sirip sebesar 0.38. Sehingga dari ketiga jenis sudu turbin tersebut, tingkat efisiensi turbin yang paling baik berdasarkan hasil pengukuran dari prototype yang telah ada adalah turbin sudu segitiga yang nilai efisiensinya sebesar 0.46 atau $46 \%$.

Nilai efisiensi pada sudut $15^{\circ}$, untuk turbin sudu setengah lingkaran memiliki nilai efisiensi paling tinggi, kemudian turbin sudu segitiga dan turbin sudu sirip yang memiliki nilai efisiensi paling rendah. Perubahan nilai tinggi efisiensi setiap sudut berbeda-beda, dikarenakan jenis sudu masing-masing turbin memiliki kharakteristik sudu yang berbeda.

Pada sudut $30^{\circ}$, diketahui bahwa nilai efisiensi setiap turbin mencapai titik tertinggi, sedangkan lebih dari $30^{\circ}$, nilai efisiensinya berkurang. Berkurangnya efisiensi turbin pada sudut $35^{\circ}$ disebabkan karena jatuh air dari nozzle tidak
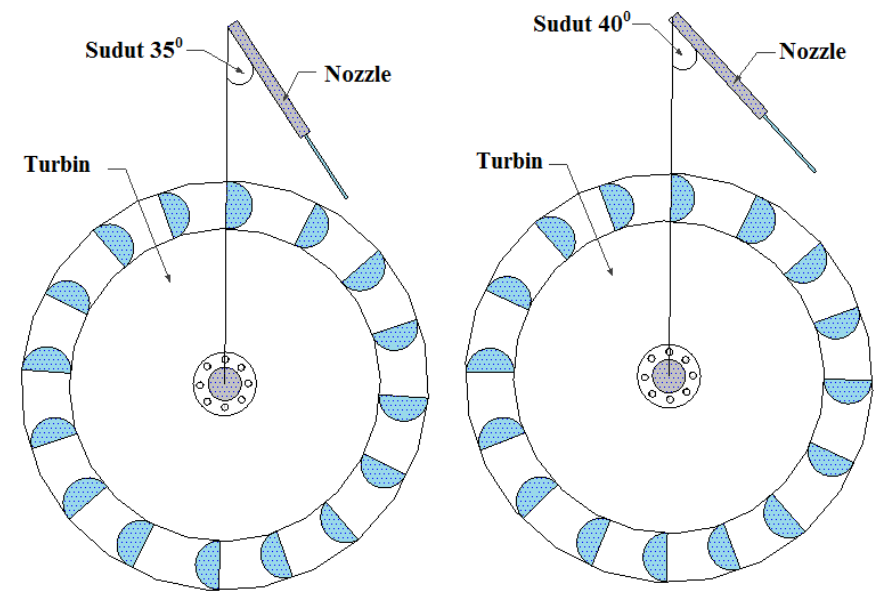

Gambar 5: Sudut Nozzle $35^{\circ}$ dan $40^{\circ}$ Terhadap Turbin

sepenuhnya mengenai sudu turbin, sehingga turbin tidak terdorong dengan sempurna. Sedangkan pada sudut $40^{\circ}$ jatuh air dari nozzle tidak mengenai sudu turbin sama sekali, artinya turbin tersebut tidak ada dorongan air untuk membuatnya berputar.

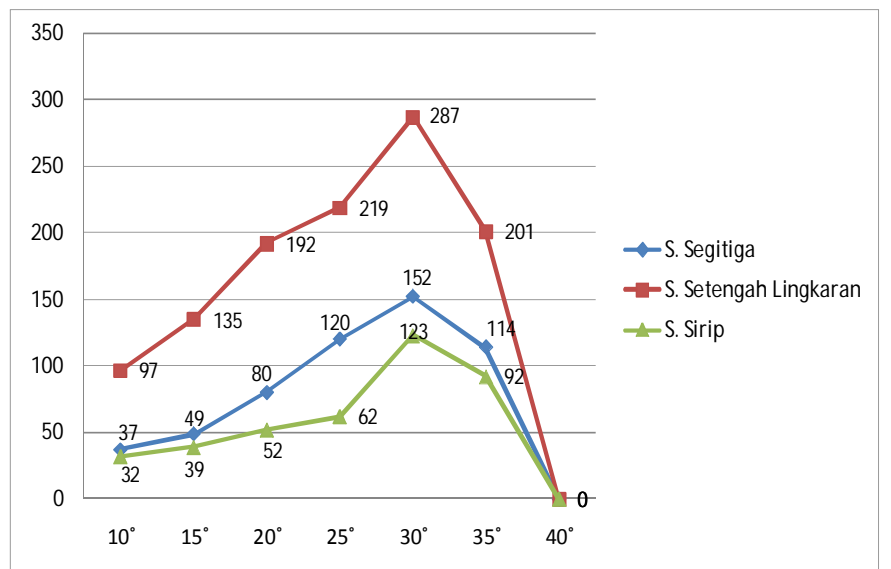

Gambar 6: Hubungan Sudut Nozzle Terhadap Putaran Turbin Masing-Masing Sudu

\section{KESIMPULAN}

Modul praktikum dirancang berdasarkan acuan dari hasil prototype PLTMH yang telah ada. Untuk mengimplementasikan modul praktikum PLTMH maka disusunlah petunjuk - petunjuk praktikum dengan mengacu pada pengukuran yang dapat dilakukan dengan prototype PLTMH tersebut.

Prosedur pengukuran dalam praktikum PLTMH dirancang untuk mengetahui bagaimana prinsip kerja prototype dengan parameter yang dapat diukur yaitu Arus (I), Tegangan (V), Daya (P), Debit Air (Q), Putaran Turbin (nt), dan Putaran Generator (ng) dengan sudut nozzle $10^{\circ}, 15^{\circ}, 20^{\circ}, 25^{\circ}, 30^{\circ}, 35^{\circ}$, dan $40^{\circ}$ untuk setiap percobaan, dengan tiga macam jenis sudu 


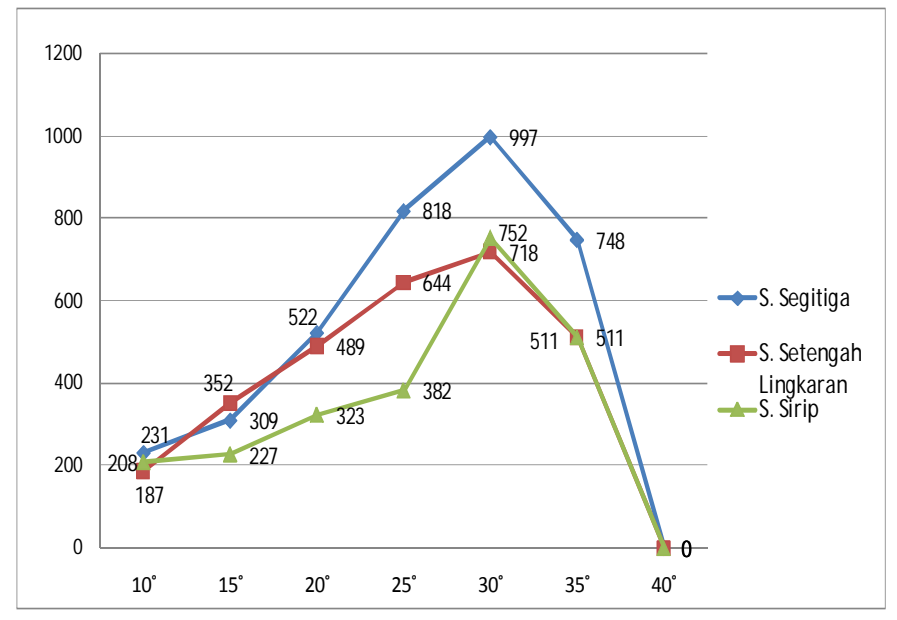

Gambar 7: Hubungan Sudut Nozzle Terhadap Putaran Generator Masing-Masing Sudu Turbin

turbin yang berbeda, serta dapat menentukan efisiensi dan regulasinya. Dalam penelitian ini, efisiensi turbin pada masing - masing sudu dari sudut $10^{\circ}$ sampai $30^{\circ}$, nilai efisiensinya terus naik mencapai titik tertinggi pada sudut $30^{\circ}$. Sedangkan pada sudut $35^{\circ}$ dan $40^{\circ}$, nilai efisiensi pada masing - masing jenis sudu turbin berkurang.

Berkurangnya nilai efisiensi turbin pada sudut $35^{0}$ disebabkan karena jatuh air dari nozzle tidak sepenuhnya mengenai turbin, sehingga air tidak dapat mendorong turbin untuk berputar sempurna. Dan pada sudut $40^{\circ}$ jatuh air dari nozzle tidak mengenai sudu turbin sama sekali, artinya turbin tersebut tidak ada dorongan air untuk membuatnya berputar.

\section{REFERENSI}

[1] Jasa, L., "Mengatasi Krisis Energi Dengan Memanfaatkan Aliran Pangkung Sebagai Sumber Pembangkit Listrik Alternatif'. Bali: Universitas Udayana. 2010.

[2] Jasa, L., Ardana, P., Setiawan, I. N. Usaha Mengatasi Krisis Energi Dengan Memanfaatkan Aliran Pangkung Sebagai Sumber Pembangkit Listrik Alternatif Bagi Masyarakat Dusun Gambuk -Pupuan, Tabanan. in Proceding Seminar Nasional Teknologi Industri XV, ITS, Surabaya, pp. B0377-B0384, 2011

[3] Weking, dkk., Modul Simulasi Kontrol Hidro Power Untuk Praktikum Mahasiswa Teknik Elektro Universitas Udayana, 2015.

[4] Djiteng, M., Pembangkitan Energi Listrik, Jakarta: Erlangga, 2005.

[5] Djiteng, M.,Operasi Sistem Tenaga Listrik, Yogyakarta: Graha Ilmu, 2006.

[6] Suparyawan, D, P, D., Studi Perencanaan Pembangkit Listrik Mikrohidro Di Desa Sambangan Kabupaten Bulelen Bali. Bali: Universitas Udayana.2013.

[7] Larasakti, dkk. "Pembuatan dan Pengujian Pembangkit Listrik Tenaga Mikrohidro Turbin Banki Daya 200 Watt". Makasar: Universitas Hasanudin, 2012.

Achmad Bahri: Merancang Dan Mengimplementasi Modul ...

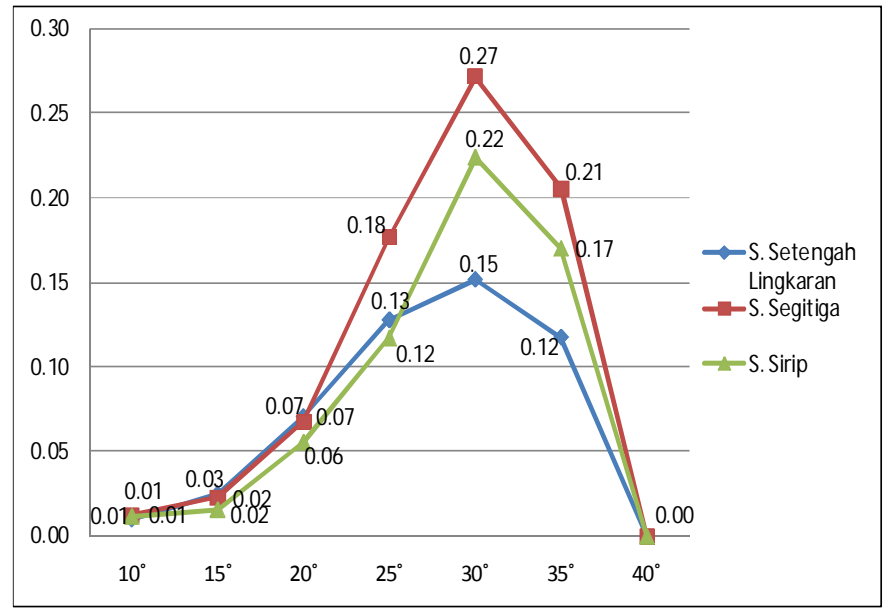

Gambar 8: Perbandingan Sudut Terhadap Daya Output 